Business and Economics Research Journal

Volume 8 Number 2017

pp. $259-273$

ISSN: $1309-2448$

DOI Number: 10.20409/berj.2017.49

\title{
Beş Yıldızlı Otel İşletmelerinde Kriz Dönemlerinde Uygulanan Tasarruf Stratejilerinin Bulanık DEMATEL Yöntemiyle İncelenmesi
}

\author{
Nisa Ekşilia
}

Zeynep Ünal ${ }^{b}$

Emre İpekçi Çetin ${ }^{c}$

\begin{abstract}
Öz: 2015 yılının sonunda Türkiye ile Rusya Federasyonu arasında yaşanan kriz birçok sektörde olduğu gibi turizm sektöründe de önemli olumsuz etkilere sebep olmuştur. Kültür ve Turizm Bakanlığı'nın verilerine göre, Ocak-Aralık 2016 arasında Rusya Federasyonu'ndan Türkiye'ye gelen toplam ziyaretçi sayısının bir önceki yıla göre \% 76.26 azaldığı görülmektedir. Krizle mücadele etmek zorunda olan konaklama işletmeleri birtakım tasarruf stratejileri geliştirerek sektörde kalma gayreti içine girmişlerdir. Bu çalışmanın amacı, kriz karşııında beş yıldızlı oel işletmelerinin tasarruf stratejilerinin bulanık DEMATEL yöntemi ile incelenmesidir. Çalışmada öncelikle beş yıldızlı otel işletmelerinin krizler karşııında uyguladıkları tasarruf stratejileri, ilgili literatürden ve Antalya'da faaliyet gösteren beş yıldızlı otel işletmesi genel müdürleriyle yapılan yüz yüze görüşmeler neticesinde tespit edilmiştir. Daha sonra bu tasarruf stratejilerinin birbirleriyle olan ilişkisi çok kriterli karar verme tekniklerinden biri olan bulanık DEMATEL yönteminin kullanımıyla değerlendirilmiştir. Belirlenen yedi tasarruf stratejisinden "Tüm departmanlarda personel sayısını azaltmak" stratejisinin uygulanan diğer stratejilerden en çok etkilenen strateji olduğu görülmüşür.
\end{abstract}

Anahtar Sözcükler: Kriz Yönetimi, Tasarruf Stratejileri, Bulanık DEMATEL Yöntemi, Konaklama Sektörü

JEL Sınıflandırması: M10, C61

\section{Analyzing Retrenchment Strategies of Five Star Hotels during the Crisis Periods Using Fuzzy DEMATEL Method}

\begin{abstract}
The crisis emerged between Turkey and Russia at the end of 2015 caused significant negative effects on the tourism sector as well as on many sectors. According to the Ministry of Culture and Tourism, the number of Russian Federation tourists coming to Turkey between January and December 2016 decreased by 76,26\% compared to the same period of previous year. Hotels, which have to fight against the crisis, have made an effort to survive in the sector by developing a number of retrenchment strategies. The aim of this study is to examine the retrenchment strategies of five star hotels during the crisis periods with the fuzzy DEMATEL method. Firstly, the retrenchment strategies applied against the crises used in this study were determined by reviewing the related literature and face to face interviews with the general managers of five star hotels located in Antalya. Then the interrelationship of these retrenchment strategies was evaluated by using a multi-criteria decision making technique, the fuzzy DEMATEL method. It was stated that the strategy "Reduce the number of staff in all departments" was the most affected strategy among the other seven retrenchment strategies.
\end{abstract}

Keywords: Crisis Management, Retrenchment Strategies, Fuzzy DEMATEL Method, Hospitality Industry

JEL Classification: M10, C61

\footnotetext{
aLecturer, Akdeniz University, Vocational School of Social Sciences, Business Administration Program, Antalya, Turkiye, nisaeksili@akdeniz.edu.tr

bPhD. Student, Akdeniz University, Institute of Social Sciences, Department of Econometrics, Antalya, Turkiye, zeynepunal1010@hotmail.com

'Assoc. Prof., PhD., Akdeniz University, Faculty of Economics and Administrative Sciences, Department of Econometrics, Antalya, Turkiye, ecetin@akdeniz.edu.tr
} 


\section{Giriş}

Teknolojik, sosyal ve ekonomik gelişmelerle birlikte küreselleşen pazar ve uluslararası boyutta yaşanan rekabet bazen krizleri de beraberinde getirmektedir. Dünyada terörist saldırılar, siyasi istikrarsızlık, ekonomik durgunluk, biyo-güvenlik tehditleri ve doğal afetler de dâhil olmak üzere birçok kriz ve felaket yaşanmıştır (Faulkner, 2001). 2015 yııının Kasım ayında Türk Hava Kuvvetleri tarafindan düşürülen Rus savaş uçağı Türkiye ile Rusya Federasyonu arasında birtakım sorunların oluşmasına sebep olmuştur. Gerek yaşanan ekonomik kriz gerekse iki ülke arasında yaşanan gerilim özellikle turizm ve tarım sektörleri başta olmak üzere Türkiye'de birçok sektörü etkilemiştir. Bunun yanında turizm sektörünü hedef alan terörist saldırılar da bu etkiye katkıda bulunmuştur.

Geçmişte yaşanan krizler (1994 Ekonomik Krizi, Kasım 2000 Ekonomik Krizi, Şubat 2001 Krizi, 2008 Ekonomik Krizi), krizlerin etkilerinin kısa süreli olmadığını göstermiştir. Özellikle 2008 krizi küresel düzeyde on beş ay devam ederek uluslararası turist sayısında \%12 azalmaya neden olmuş ve dünya turizm sektöründe karşılaşılan çok ciddi bir ekonomik kriz olarak değerlendirilmiştir (Ayaz, 2016). Sektörel, ulusal veya küresel bazda yaşanan bu tarz krizler, Türkiye gibi gelişmekte olan ülkelerdeki işletmelerin hayatta kalmalarını güçleştirmektedir. Yaşanan krizler işletmeleri, krizle mücadele stratejileri geliştirmekle birlikte krize karşı hazırlıklı olmaya zorlamaktadır. Nitel ve nicel olarak artan konaklama tesisleri ve havayolu şirketleri, giderek şiddetlenen rekabet ortamında Türkiye'nin yerini ve önemini artırmaktadır. Bu nedenle, turizm sektörünün ulusal ekonomideki ve küresel pazardaki yerinin ve öneminin doğru algılanması ve sektörün özelliklerine uygun politikalar üretmeye ağırlık verilmesi gelişimi hızlandıracaktır. Bu düzenlemelerin yanında, var olan ve olası krizlere karşı etkin ve verimli mücadele stratejileri belirlenmesi ve uygulanması ile krizin etkileri minimize edilecek ve sektörün gelişim hızı sekteye uğramayacaktır (Bahar, Kaya ve Keklik, 2011).

\section{Kavramsal Çerçeve}

Bir işletmenin operasyonlarını, finansal durumunu ve yaşamını tehlikeye sokan, müşterilerini ve çalışanlarını bedenen ve ruhen tehdit eden, işletmenin iç veya dış ortamından kaynaklanan plansız bir olay ya da durum olarak tanımlanan kriz (Kash ve Darling, 1988), beklenmedik veya önceden sinyal verdiği halde belirtilerinin çeşitli nedenlerden dolayı geç veya yanlış anlaşıldığı bir durumu ifade etmektedir (Mitroff, 2000). Kriz meydana geldiğinde krize karşı koyabilmek için neler yapılması gerektiğinin belirlenmesi ve planlanması süreci olarak tanımlanan kriz yönetimi işletmeler için hayati önem taşımaktadır. İşletmeler için krize karşı hazırlıklı olma, krizin genellikle olumsuz olan etkilerini ortadan kaldırmak için oldukça önemlidir (Okumuş, Altnnay ve Araslı, 2005; Davies ve Walters, 1998). İşletmelerin varlığını tehdit eden kriz durumundan en az kayıpla kurtulmayı sağlayacak doğru politikaların belirlenmesi ve doğru önlemlerin alınması gerekmektedir. İşletmelerin başarısı bu tür tehlikelere karşı ayakta kalabilmeleriyle ölçülmektedir (Bahar vd., 2011).

Krizlerin sebeplerini işletme içi ve işletme dışı faktörler olmak üzere iki başlık altında toplamak mümkündür. İşletmenin kontrolünün dışında oluşan ve denetlenemeyen dış faktörler, çok hızlı bir değişim ve belirsizlik artışı durumunda karar verme sürecinde yaşanan aksaklıklara bağlı olarak krizin kendini göstermesine neden olur. Bu faktörler arasında uluslararası olaylar, doğal afetler, ekonomik ve politik olaylar, ani değişimler, teknolojik gelişmeler, yasal düzenlemeler ve güçlü rakipler sayılabilir. İşletmenin kontrolü altında olan, içyapısında ve yönetim kademelerinde meydana gelen olaylar iç faktörler arasında sayılabilir. Yönetimin yetersizleşmesi, yeterli bilgi sistemlerinin olmayışı, alışkanlıklar ve deneyimler, işletme içi körlük gibi faktörler iç faktörler arasındadır (Eren, 2013).

Kriz sebeplerinin kriz türleriyle yakın ilişkisi vardır. Parsons (1996), anlık krizler, gelişmekte olan krizler ve sürekli krizler olmak üzere üç tür krizden bahsetmektedir:

1. Anlık krizler: Çıkışlarıyla ilgili ya çok az belirti olan ya da hiç belirti olmayan krizlerdir. Dolayısıyla işletmelerin bu tarz krizleri tespit etmeleri ve önlemler almak için planlar yapmaları mümkün değildir.

2. Gelişmekte olan krizler: Bu krizler yavaş gelişir. Dolayısıyla gelişme esnasında işletmenin eylem planları sayesinde işletmeyi etkilemesi engellenebilen krizlerdir. 
3. Sürekli krizler: Haftalar, aylar hatta yıllarca sürebilen krizlerdir. İşletmeler bu krizler ile yaşamanın çaresini bulmalıdırlar.

İşletmeler bir krizle karşılaştkklarında, kriz yönetimi gereği çevresel koşullar, örgüt kültürleri, iklimleri ve özelliklerine uygun olarak bazı politikalar izlerler. Satı̧ politikasını değiştirme, yeni pazarlara girme, mamul çeşitlendirme, satış gelirlerini artırma, alacak devir hızını artırma, borçları erteleme, sermaye artırımına gitme, birleşme veya satma, insan kaynaklarını eğitme, planlı bakım ve onarım sistemi kurma, AR-GE' ye önem verme, yönetici yetiştirme, pazar çeşitlendirme, pazara nüfuz etme, yenilikçi personel çalıştırma, problemleri anında çözme, kalifiye personeli çıkarmama, personel ücret indirimlerine gitme, çalışanların potansiyelini açığa çıkarma, yarı zamanlı çalışma sistemine geçmek, ihracat imkânlarını araştırma, katma değer yaratmayan ürünleri tasfiye etme, yeni borçlara girmeme, riski dağıtma, plansız büyümeme, mali oranları sürekli izleme, her türlü tasarruf tedbirine başvurma (Çelik ve Özdevecioğlu, 2002) bu politikalar arasındadır.

İşletmelerin özellikle kriz dönemlerinde uzun bir süre boyunca performans düşüklüğü yaşamasının ardından işletmenin uyguladığı stratejiler, sistemler ve yetenekler sayesinde sürdürülebilir kârlıık elde etmeye başlaması işletmenin dönüşü anlamına gelmektedir (Chowdhury, 2002; Solnet, Paulsen ve Cooper, 2010; Pearce ve Robbins, 2008). Bu geridönüşün üç stratejik yaklaşımı vardır. Bunlar (i) üst yönetim ekibini değiştirme, (ii) tasarruf stratejileri uygulama, ve (iii) stratejik uyumlaştırmadır (Chowdhury, 2002).

Bu çalışmaya konu olan tasarruf stratejileri, kurumsal yönetim stratejilerinden çekilme stratejilerinin bir türüdür. Tasarruf stratejileri, yoğun ve olumsuz etki yapan dış çevre baskıları karşısında işletmenin, faaliyetlerini verimliliği arttracak çabalar üzerine yöneltmesi ile ilgilidir (Dinçer, 1998: 294). İşletmenin mali durumunun zayıflaması ve üstünlüklerini kaybetmesi sonucunda uygulanan tasarruf stratejileri, işletmenin belirli bir süre için geliştirme ve büyüme faaliyetlerini azaltmasına ve tüm dikkat ve uğraşlarını işletme içi verimliliğin yükseltilmesine yöneltmesini ifade eder. Bu stratejilerin uygulanma sebebi, işletmenin mevcut olumsuz finansal durumunun tasarruf önlemleri ile düzeltilebilir olmasıdır. İşletmelerde zayıflamış olan finansal durumun çeşitli nedenleri olabilir. Ancak bu nedenler işletmede aşırı ve büyük değişiklikler yapılmadan tasarruf stratejileriyle düzeltilebilecek nedenlerdir (Ülgen ve Mirze, 2013). Defansif stratejiler olarak da adlandırılan tasarruf stratejilerinin uygulanması ile performansın arttırılarak işletmenin etkinleştirilmesi mümkündür. Tasarruf stratejilerinden biri olan "turnaround", "downsizing" yapılarak gerçekleştirilir. Yöneticiler bu yol ile personel sayısının, yatırım harcamalarının, yönetim ve genel giderlerin kısılmasının yanında satın alma ve stok denetimlerinin sıklaştrılması ile maliyetlerin azaltılmasını sağlayabilmektedirler. Alacakların takibi ve nakit akışlarının hızlandırılması ile de gelir artışı sağlanmaya çalışılmaktadır. Diğer bir tasarruf stratejisi ise "yeniden yapılanma"dır. Bu stratejiyle üretim sürecinin etkinliği arttırılmaya çalışılır. Ürünlerde iyileştirici gelişmeler yapılması gibi konularda önlemler alarak verimlilik arttırmaya çalışmaktadırlar. Tasarruf stratejilerinden bir diğeri ise organizasyonun bazı bölümlerinin satılmasıyla maliyetlerin azaltılmasına gitme yöntemi olan "divesteture"dur. Bunların yanında "likiditasyon" yolu ile de tasarruf stratejisi uygulanabilir. Bu stratejide bütün varlıklar satılarak çalışmaların durdurulması söz konusudur (Akdemir, 2009; Ülgen ve Mirze, 2013).

Genel olarak incelendiğinde, konaklama işletmelerinin tasarruf kalemleri personel giderleri, enerji giderleri, satın alma giderleri ve diğer giderler olmak üzere dört ana başlık altında toplanabilir. Her ne kadar otomasyon sistemleri kullanılsa da emek yoğun bir sektör olan konaklama sektöründe insan kaynağı en önemli girdidir. Gerek niteliksel gerek niceliksel olarak hassasiyetle planlanmalıdır (AKTOB, 2014; Avcı ve Küçükusta, 2009) Kriz dönemlerinde tasarruf stratejileri kapsamında işletmeler çalışanları üzerine oldukça fazla yoğunlaşırlar. Genel giderlerin yaklaşık \%45 'ini oluşturan personel giderleri çoğu zaman yönetim tarafindan ilk tasarruf kalemi olarak düşünülmektedir. Ancak bu hamlenin uzun vadeli sonuçlarının çok iyi analiz edilmesi gerekmektedir. Konaklama işletmelerinde doğal gaz, elektrik ve su olmak üzere kullanılan enerji çeşitleri genel giderlerin içinde yaklaşık \%10-15 paya sahiptir. İşletme içinde diğer giderler ise yaklaşık $\% 10$ 'luk bir paya sahiptir. Yiyecek içecek, kat hizmetleri gibi operasyon departmanlarının satın alma giderleri genel giderlerin \% 25-30'u civarındadır (AKTOB, 2014). Kaynak verimliliğini sağlamak satıcılarla fiyat ve ödeme şartları konusunda yeni düzenlemeler yapmak, toplu alımlar (Whitlaa, Waltersb ve Davies, 2007), maliyeti yüksek ürün ve hizmetleri daha düşük maliyetli olanlarıyla değiştirmek satın alma giderlerinin düşürülmesini sağlamaktadır. Ancak bu noktada işletmenin hizmet standardını koruyabilmek çok önemlidir. 
Personel giderleri, enerji giderleri ve satın alma gibi giderlerin düşürülmesinin yanında verimliliği ve etkinliği arttırmak için tüm departmanlardaki iş süreçlerini misafir memnuniyetini karşılayacak şekilde yeniden tasarlamak, operasyonun daha etkin kontrolü için yeni bilgi sistemleri teknolojilerinden yararlanmak ve yeni yatırım giderlerini durdurmak da işletmenin maliyetlerinin düşürülmesine yardımcı olmaktadır. Burada dikkat edilmesi gereken konu verimliliği geliştirecek olan gider ve yatıımlardaki kısıtlamaların, işletmenin rekabet gücünü etkileyecek temel yetenekler ve kilit başarı faktörlerinde uygulanmamasıdır (Ülgen ve Mirze, 2013). Bu sebeple hangi alanlarda ve ne ölçüde tasarruf yapılması gerektiği, işletme açısından alınması gereken stratejik bir karardır. Üst yönetim ekibinin bu kararı alabilmesi için edinmesi gereken birçok bilgi ve hem sektörel hem de işletme bazında analiz sonuçlarına ihtiyacı vardır.

Hizmet işletmeleri olması sebebiyle kriz dönemi ve krizden etkilenme şartları dikkate alındığında konaklama işletmeleri ulusal ve uluslararası krizlerden ilk etkilenecek işletmelerdendir. Konaklama işletmeleri mevsimsel şartlarda hizmet verdiğinden, genel olarak belirli dönemlerde yoğun olarak çalışan, belirli dönemlerde ise atıl kalan işletmelerdir. Gerek üst, orta ve gerekse alt kademe yöneticiler nitelikli olmalıdır. Üretilen hizmet lüks tüketim malı sayılabileceği için, genel ekonomik krizlerde ilk terk edilecek hizmet kategorisine girmektedir. Ürün depolanmadığı için üretildiği anda tüketilmesi gerekmektedir. Üretilen hizmetin niteliği toplumun demografik özellikleri ve yaşam şekli ile yakından ilgili olduğu için toplumsal ve ekonomik faktörler hissedilir derecede etkiler yaratır. Sunulan hizmetlerin çeşitlendirilmesi diğer sektörlere oranla oldukça güçtür. Misafir ile çalışan yüz yüze olduğundan memnuniyet ya da memnuniyetsizlik doğrudan işletme yönetimine iletilecek ve etkilenme oranı daha yüksek olacaktır (Boyd ve Walker, 1999).

\section{DEMATEL Yöntemi}

Bu çalışmada kriz dönemlerinde beş yıldızlı otel işletmelerinde uygulanan tasarruf stratejilerinin ve etkilerinin Bulanık DEMATEL (The Decision Making Trial and Evaluation Laboratory- Karar verme deneme ve değerlendirme laboratuarı) yöntemiyle değerlendirilmesi amaçlanmaktadır. Birden çok kriterin göz önüne alınarak alternatifler arasından bir seçim yapma süreci Çok Kriterli Karar Verme olarak bilinmektedir. AHP, TOPSIS, Electre, Promethee gibi gelenekselleşmiş yöntemlerin yanı sıra yeni gelişen veya uygulamaları son dönemde artan pek çok yöntem vardır. Bu yöntemlerden birisi de bu çalışmanın uygulama kısmında ele alınmış olan DEMATEL yöntemidir. Çalışmada 2015 yılı sonunda Türkiye ile Rusya Federasyonu arasında yaşanan kriz dönemi dikkate alınmıştır. Hem Türkiye'de turizm sektöründe 2016 yılı açısından konunun güncelliği, hem de tasarruf stratejileri ile çok kriterli karar verme yöntemlerinin bir arada kullanıldığı çalışma sayısının sınırlı olmasının çalışmayı değerli kıldığı düşünülmektedir.

DEMATEL yöntemi ilk kez 1973 yılında Cenevre Araştırma Merkezi bünyesinde yer alan "The Battelle Memorial Institute"de yapılan bir çalışmada uygulandıktan sonra yapısal bir model oluşturmak amacıyla geliştirilip bir yöntem haline gelmiştir (Aksakal ve Dağdeviren, 2010). DEMATEL, bilimsel araştrrma yöntemlerinin kullanımı sayesinde belirli bir sorunun daha iyi anlaşılacağı inancıyla geliştirilmiştir. Yöntem karar problemlerinde kullanılmakta olup problemin temel özelliklerini ön plana çıkararak gerekli önlemlerin alınmasında yardımcı olmaktadır (Chen, 2012). DEMATEL bir konunun unsurları arasında karmaşık ilişkileri analiz etmeye yarayan bir yöntem olup, sistemde etkili değişkenleri bir sebep ve sonuç diyagramı şeklinde göstermektedir. DEMATEL sonuçları kullanılarak, yöneticilerin ve araştırmacıların değişkenler arasındaki ilişkileri tam olarak algılaması sağlanabilmektedir (Saeidipour ve Ismaeli, 2012).

DEMATEL yöntemi aşağıda detayları ile anlatılan dört adımdan oluşmaktadır (Hwang, Pai, Lu ve Ken, 2014).

1. Adım: Direkt ilişki matrisinin oluşturulması.

$x_{i j}^{k}$ değeri sayısal değer olup k. uzman tarafindan i.kriterin j.kritere etkisinin derecesini ifade etmektedir. $\mathrm{H}$ sayıda uzman kriterlerin birebiriyle olan ektilerini değerlendirerek $\mathrm{H}$ adet $\mathrm{nxn}$ direkt ilişki matrisi elde edilir. Elde edilen bu matrislerin (1) nolu formül vasıtasıyla ortalamaları alınarak ortalama direkt ilişki matrisi (A) oluşturulur. 


$$
a_{i j}=\frac{1}{H} \sum_{k=1}^{H} x_{i j}^{k}
$$

Uzman tarafindan yapılan değerlendirmeler Tablo 1'deki ölçeğe göre yapılmaktadır (Aksakal ve Dağdeviren, 2010).

Tablo 1. DEMATEL Değerlendirme Ölçeği

\begin{tabular}{cc}
\hline Sayısal Değer & Tanım \\
\hline 0 & Etkisiz \\
1 & Düşük etki \\
2 & Orta etki \\
3 & Yüksek etki \\
4 & Çok yüksek etki \\
\hline
\end{tabular}

2. Adım: Normalleştirilmiş direkt-ilişki matrisinin elde edilmesi.

Bir önceki adımda elde edilen ortalama direkt ilişki matrisi (A), (2) ve (3) nolu formüller kullanılarak normalleştirilmiş direkt-ilişki matrisi $(X)$ haline getirilir.

$$
X=k \cdot A
$$

$$
k=\frac{1}{\max \sum_{j=1}^{n} a_{i j}}, \quad i, j=1,2, \ldots, n
$$

3. Adım: Toplam-ilişki matrisinin elde edilmesi.

Bir önceki adımda elde edilen normalleştirilmiş direkt-ilişki matrisi $(X)$ ve (4) nolu formül kullanılarak toplam-ilişki matrisi $\left(T_{c}\right)$ elde edilir. Buradaki I birim matrisi temsil etmektedir.

$$
T_{C}=X(I-X)^{-1}
$$

4. Adım : Etki diyagramı için değerlerin elde edilmesi.

Elde edilen toplam ilişki matrisinde $\left(\mathrm{T}_{\mathrm{c}}\right)$ satıların ve sütunların toplamları şeklinde (5) ve (6) formülleri kullanılarak $r$ ve c vektörleri elde edilir. Etki diyagramında önemi temsil eden yatay eksen değerleri olacak noktalar $(r+c)$ bu iki vektörün değerleri toplanarak elde edilir. Aynı şekilde ektiyi temsil eden dikey eksen değerleri olacak noktalar $(r-c)$ bu iki vektörün değerleri birbirinden çıkarılarak elde edilir.

$$
\begin{aligned}
& T=\left[t_{i j}\right]_{n x n}, \quad i, j=1,2, \ldots, n \\
& r=\left[\sum_{j=1}^{n} t_{i j}\right]_{n x 1}=\left[t_{i}\right]_{n x 1} \\
& c=\left[\sum_{i=1}^{n} t_{i j}\right]_{1 x n}=\left[t_{j}\right]_{1 \times n}
\end{aligned}
$$

\subsection{Bulanık DEMATEL Yöntemi}

Genellikle belirsiz bir ortamda gerçekleşen karar alma süreçlerinde keskin (crisp) değerlerin kullanılması sakıncalı bir durumdur. İnsanların tercihler hakkındaki kararları genellikle belirsizlik içerdiği için kesin değerlendirmelerle bu belirsizliği açıklamaları zor olduğu gibi karmaşık faktörler arasındaki etkileşimin 
ne derece olduğunun belirlenmesi de ayrı bir güçlüktür. Bu nedenle DEMATEL yöntemi bulanık ortamlarda daha gerçekçi kararlar almak için bulanık küme teorisi ile birleştirilip, bulanık DEMATEL yöntemi olarak literatüre girmiştir (Türker, 2012).

Bulanık küme teorisi, belirsizliği ifade etmede yararlanılan bir yöntem olup karar vericilere dilsel değişkenlerden faydalanarak değerlendirmelerini yapma imkânı sunmaktadır. Bulanık DEMATEL yöntemi oldukça yeni bir teknik olmakla beraber bu yöntemin kullanıldığı çalışmaların sayısında son yıllarda artış söz konusudur (Bali, Tutun, Pala ve Çörekçi, 2014).

DEMATEL yönteminde ilişkilerin tespiti için uzmanların görüşlerinden faydalanma noktasında karar verici/uzmanlardan net olarak bilgi alınamayabilir çünkü değerlendiricilerin sayısal ölçeklerle düşündüklerini net bir şekilde ifade etmede zorlandıkları görülmüştür. Literatür incelendiğinde, bu sıkıntıyı aşmak adına bulanık DEMATEL yönteminde dilsel ifadelerin yaygın bir şekilde kullanıldığı görülmektedir. Bulanık DEMATEL yöntemi aşağıdaki adımlardan oluşmaktadır (Eroğlu, Canlı ve Gülşan, 2015).

1. Adım: Kriterlerin Belirlenmesi ve Bulanık Ölçeğin Tespiti

Problemin tipine göre literatürden veya konuyla ilgili uzman kişilerle yapılan anket veya yüz yüze görüşmelerden yararlanarak kriterler tespit edilir. Bulanık ölçeğin tespitinde üçgensel, yamuk veya başka üretilmiş bulanık sayılar kullanılabilir. Bu çalışmada tercih edilen üçgensel bulanık sayılar içeren bulanık dilsel ölçek Tablo 2'de verilmiştir (Chang, Chang ve Wu, 2011; Wu ve Lee, 2007).

Tablo 2. Bulanık Dilsel Ölçek

\begin{tabular}{ccc}
\hline Dilsel ifadeler & Etki Skoru & Üçgensel Bulanık Sayılar \\
\hline Etkisiz & 0 & $(0 ; 0 ; 0,25)$ \\
Düşük etki & 1 & $(0 ; 0,25 ; 0,50)$ \\
Orta etki & 2 & $(0,25 ; 0,50 ; 0,75)$ \\
Yüksek etki & 3 & $(0,50 ; 0,75 ; 1,00)$ \\
Çok yüksek etki & 4 & $(0,75 ; 1,00 ; 1,00)$ \\
\hline
\end{tabular}

Bir bulanık Ã kümesinde üçgensel bulanık sayılar $(I, m, u)$ olarak 3 değerle ifade edilir ve üyelik fonksiyonu aşă̆ıdaki gibi tanımlanır (Bali vd., 2014).

$$
\mu_{\tilde{A}}(x)=\left\{\begin{array}{cc}
0, & x<l \\
(x-l) /(m-l), & 1 \leq x \leq m \\
(u-x) /(u-m), & m \leq x \leq u \\
0, & x>\mathrm{u}
\end{array}\right.
$$

Burada $\mathrm{I}, \mathrm{m}$ ve u gerçel sayılardır ve $\mathrm{I} \leq \mathrm{m} \leq \mathrm{u}$ olması gerekmektedir.

2. Adım: Bulanık Direkt İlişki Matrisinin Oluşturulması

Bu adımda dilsel ölçek kullanılarak karar verici veya uzmanlardan ikili karşılaştırma yapmaları yani belirlenen kriterlerin bir birine ektisini derecelendirmeleri istenmektedir. Direkt ilişki matrisi simetrik olmadığı için bir kriterin diğerine etkisi değerlendirilirken, ters etkisinin de değerlendirilmesi gerekmektedir. Bu matriste köşegen elemanları 0'dır (Eroğlu vd., 2015). Bulanık DEMATEL yönteminin bu adımı klasik DEMATEL yöntemine benzer bir şekilde yapılmaktadır, tek fark değerlendirmelerde üçgensel bulanık sayıların kullanılmasıdır. Ortalama direkt ilişki matrisi elde edilirken ise üçgensel bulanık sayıların ortalamasının alınması gerekmektedir. 
3. Adım: Normalleştirilmiş Bulanık Direkt İlişki Matrisinin Oluşturulması

Normalleştirilmiş bulanık direkt ilişki matrisi $\left(\widetilde{\mathrm{A}}=\left[\tilde{\mathrm{a}}_{\mathrm{ij}}\right]_{\mathrm{nxn}}\right)$ ile gösterilir ve (7) ve (8) nolu formüller kullanılarak bulunur. Matrisin diyagonal elemanları sıfira eşitlenir (Bali vd., 2014).

$$
\begin{aligned}
& \tilde{a}_{i j}=\frac{\tilde{Z}}{s}=\left(\frac{l_{i j}}{s}, \frac{m_{i j}}{s}, \frac{u_{i j}}{s}\right) \\
& s=\max _{1 \leq i \leq n}\left(\sum_{i=1}^{n} l_{i j}\right) s=\max _{1 \leq i \leq n}\left(\sum_{i=1}^{n} m_{i j}\right) s=\max _{1 \leq i \leq n}\left(\sum_{i=1}^{n} u_{i j}\right)
\end{aligned}
$$

4. Adım: Bulanık Toplam İlişki Matrisinin Oluşturulması

Bir önceki adımda elde edilen normalleştirilmiş bulanık direkt ilişki matrisi üç matrise ayrılabilir. Ayrılan bu matrisler $A_{l}, A_{m}$ ve $A_{u}$ olarak gösterilir ve her bir matrisin klasik DEMATEL bölümünde verilen (4) nolu denklem kullanılarak toplam ilişki matrisi elde edilir.

5. Adım: Etkilenen ve Etkileyen Grupların Belirlenmesi

Bu adımda DEMATEL yönteminin adımları kısmında gösterilen (5) ve (6) nolu formüller $A_{l}, A_{m}$ ve $A_{u}$ matris için ayrı ayrı uygulanır ve etki diyagramında yatay eksen dikey eksen değerleri $r_{l}+c_{l}, r_{l}-c_{l}, r_{m}+c_{m}, r_{m}-$ $c_{m}, r_{u}+c_{u}$ ve $r_{u}-c_{u}$, değerleri bulunur.

6. Adım: Durulaştırma

Durulaştırma için literatürde birçok yaklaşım bulunmaktadır. Bu çalışmada bulanık sayıları durulaştırmak için (9) ve (10) nolu formüller kullanılmıştır (Bali vd., 2014).

$$
\begin{aligned}
& \left(\tilde{r}_{i}+\tilde{c}_{i}\right)^{D e f}=\frac{1}{4}(l+2 m+u) \\
& \left(\tilde{r}_{i}-\tilde{c}_{i}\right)^{D e f}=\frac{1}{4}(l+2 m+u)
\end{aligned}
$$

Durulaştırılmış bu değerler etki diyagramının oluşturulmasında kullanılmaktadır.

7. Adım: Kriterlerin Ağırlıklarının Belirlenmesi

Kriter ağırlıkları ise (11) ve (12) nolu denklemler kullanılarak hesaplanır. Kriter ağırlıkları sıfir ve bir arasında olup kriter toplamları bire eşit olmalıdır (Organ, 2013).

$$
\begin{aligned}
w_{i} & =\sqrt{\left[\left(\tilde{r}_{i}+\tilde{c}_{i}\right)^{\text {Def }}\right]^{2}+\left[\left(\tilde{r}_{i}-\tilde{c}_{i}\right)^{\text {Def }}\right]^{2}} \\
w_{i} & =\frac{w_{i}}{\sum_{i=1}^{n} w_{i}}
\end{aligned}
$$

DEMATEL yönteminin kullanıldığı çalışmalar incelendiğinde yöntemin bazen tek başına bazen de birden fazla çok kriterli karar verme tekniğiyle bir arada ele alındığı görülmektedir. Aksakal ve Dağdeviren (2010), uluslararası bir firma için personel seçiminde DEMATEL yöntemi ile analitik ağ sürecini (ANP) bütünleşik bir yapıda ele alarak seçim yapma işlemi üzerinde durmuşlardır. Karaatlı, Ömürbek, Işık ve Yılmaz (2016), 23 şeker fabrikasının 2008-2012 yılları arasındaki verilerini kullanarak performans değerlendirmesi yapmışlardır. Çalışmada ele alınana kriterlerin ağırııları DEMATEL yöntemiyle hesaplandıktan sonra bu ağırlıklar kullanılarak bulanık TOPSIS yöntemi ile performans değerlendirmesi yapılmıştı. Tedarik zincirlerin önemine dikkat çeken Chang vd. (2011), DEMATEL yönteminin kullanımıyla tedarikçi seçiminde etkili olan faktörlerin tespit edilmesi üzerinde durmuşlardır. Altuntaş, Selim ve Dereli (2016) tesis yeri düzenleme problemlerinde kalitatif ve kantitatif yerleşim faktörlerini bir arada ele alarak bulanık DEMATEL yöntemi ile alt önemli yerleşim yeri faktörünü tespit etmişlerdir.

Daha çok üretim yönetimi, performans değerlendirme gibi uygulama alanlarına sahip olan DEMATEL yönteminin turizm alanında kullanıldığı çalışmaların oldukça sınırlı olduğu görülmektedir. Chen (2012), 
Tayvan'da sağlık turizminin geliştirilmesi için gereken stratejilerin tespit edilmesinde DEMATEL yönteminin kullanımına dikkat çekmiştir. Wu, Zheng, Lu ve Wu (2014), kültürel mirasın korunması için düşük karbonlu seyahat yönetimi stratejilerinin belirlenmesinde DEMATEL yönteminden faydalanmışlardır. Chang (2014) çalışmasında turizm destinasyon imajında etkili olan 8 faktörü ele alarak, bu faktörler arasındaki etkileşimlerin ve derecelerinin tespitinde DEMATEL yöntemini kullanmıştır. Liu, Tzeng ve Lee (2012), hibrid çok kriterli karar verme tekniklerinin kullanımıyla turizm politikalarında çeşitli boyutları ve kriterleri ele alarak Tayvan turizm politikasının optimal planının tespit edilmesini amaçlamışlardır. Çalışmada DEMATEL temelli analitik ağ süreci ve Vikor yöntemlerinin kullanımı ile problemin çözümü üzerinde durulmaktadır.

Turizm ve konaklama sektörlerinde uygulanan kriz yönetimi ile ilgili ise ülkemizde pek çok çalışma yapılmıştır. Çelik ve Özdevecioğlu (2002), otel işletmelerinin, krizden etkilenme ve krize hazırlıklı olma durumlarını Nevşehir ve iç̧el illerinde faaliyet gösteren otel işletmelerini inceleyerek araştırmışlardır. İşletmelerin kriz nedeniyle içinde bulundukları durum ve izledikleri temel politikalar belirlenmeye çalışılmıştır. Araştrrmaya katılan otel yöneticilerinin \% 67'si krizin turizmi olumsuz etkilediğini belirtmiştir. Krizden çıkma yolları açısından araştırmaya katılan her iki ilin otel yöneticilerinin "kanaatkâr", ancak önlem geliştiren politikalara sahip olmadıkları "ayakta kalalım yeter" ifadesinde yoğunlaştıkları görülmektedir. Seçilmiş ve Sarı (2010), Türkiye'de faaliyet gösteren konaklama işletmelerinin uyguladıkları kriz yönetimi stratejileri ile yöneticilerin kriz yönetimi konularındaki görüşleri ve uygulamalarını araştırmıştır. Krizlerin konaklama işletmeleri üzerindeki en önemli olumsuz etkileri sırasıyla işletme imajının zayıflaması, kalite düşüşü, örgüt içi gerilimin artması, yatırımların yarıda kalması ve çalışanların işten çıkarılma korkusu nedeniyle motivasyonunun düşmesi olarak bulunurken oda satşları ve kârın düşmesi en son sıralarda yer almaktadır. Yöneticiler tarafindan doldurulan 75 anketin sonucunda konaklama isletmelerinin en çok uyguladıkları personel politikalarının sırasıyla, emekliye ayırmak, diğer işletmelerde görevlendirmek, çalışma günlerini azaltmak, ücretli izin vermek, işten çıkartmak ve ücretsiz izin vermek olduğunu göstermektedir. Bahar vd., (2011) konaklama işletmelerinin kriz sürecinde uygulamaya çalışttkları stratejiler üzerinde odaklanmıştır. Adana, Mersin, Antakya ve Bolu illerinde faaliyet gösteren 3, 4, 5 yıldızlı 54 konaklama işletmesinin yöneticileriyle görüşülmüştür. Çalışma bulgularına göre, işletme yöneticilerinin ekonomik krizle mücadelede önem verdikleri stratejilerden bazıları, müşterilerin şikâyetlerine acil çözümler getirilmesi, tur operatör ve acenteleri ile işbirliğine ağılık verilmesi, kriz atlatılana dek mevcut pazarı korumaya yönelik çalışmalar yapılması, reklâm ve tanıtım faaliyetlerine yönelik çalışmalara ağırlık verilmesi, müşterilerin ortak istek ve intiyaçlarını dikkate alarak ürünler sunulması şeklinde belirlenmiştir. Mesci, Ağraş ve Aslantürk'ün (2016) çalışmalarında ise dört davranışsal strateji boyutu ele alınmış ve kriz dönemlerinde yöneticilerin bu stratejilere ilişkin deneyimlerine ulaşmak için nitel bir araştırma tasarlanmıştır. Çalışmada, davranışsal stratejinin boyutları, otel işletmelerinin yöneticilerinin bakış açısıyla incelenmek istenmiştir. Araştırma sonucunda otel işletmesi yöneticilerinin kriz dönemlerindeki davranışsal strateji deneyimlerinin otel yöneticilerinin bulundukları pozisyona göre farklılaşttğı tespit edilmiştir. Otel yöneticilerinin kriz dönemlerindeki davranışları, momentum(denge), geribildirim, çıkarımsal ve beklentisel stratejiler çerçevesinde betimlenmiştir. Araştırmaya katılan otel işletmelerinde kriz dönemlerinde, yöneticilerin davranışsal stratejilerin aynı anda bir veya bir kaçına başvurdukları belirlenmiştir. Krizin oluşturduğu etkilere göre otel işletmelerinde davranışsal stratejilerin tümünü içeren kararlar alındığı, ayrıca davranışsal stratejilerin tümünün kullanım sıklığının birbirine çok yakın olduğu ifade edilmiştir.

\section{Kriz Karşısında Tasarruf Stratejilerinin Bulanık DEMATEL Yöntemiyle İncelenmesi}

2015 yılının sonunda Türkiye ile Rusya Federasyonu arasında yaşanan kriz birçok sektörde olduğu gibi turizm sektöründe de ciddi olumsuz etkilere sebep olmuştur. Kültür ve Turizm Bakanlığı'nın verilerine göre, Ocak-Aralık 2016 arasında Rusya Federasyonu'ndan Türkiye'ye gelen toplam ziyaretçi sayısının bir önceki yıla göre \% 76.26 azaldığı görülmektedir. Krizle mücadele etmek zorunda olan konaklama işletmeleri bir takım tasarruf stratejileri geliştirerek sektörde kalma gayreti içine girmişlerdir. Kriz dönemlerinde ve sonrasında işletmelerde uygulanması gereken bir takım tasarruf stratejileri bulunmaktadır. Bu çalışmada Antalya'da faaliyet gösteren beş yıldızlı otel işletmelerinin tasarruf stratejileri incelenerek bulanık DEMATEL yönteminin kullanımıyla bir değerlendirme yapılmaktadır. Çalışmada tasarruf stratejileri arasındaki ilişkilerin boyutları 
hem sayısal olarak irdelenmekte hem de görsel olarak sunulmaktadır. Bu maksatla yöntemin işleyiş süreci aşağıda adım adım anlatımaktadır.

\section{Adım: Kriterlerin Belirlenmesi ve Bulanık Ölçeğin Tespiti}

Araştırmanın evrenini Antalya'da Ar-Ge departmanı bulunan beş yıldızlı otel işletmeleri oluşturmaktadır. Misafir istek ve ihtiyaçlarına cevap verebilecek yeni ürün ve hizmetler sunarak misafir memnuniyeti hatta sadakatini kazanmak, böylece işletmenin sürekliliği ve karlılığını sağlamak amacıyla gerçekleştirilen Ar-Ge faaliyetleri işletmelerin yenilikçi özellik kazanmasında büyük öneme sahiptir. Ar-Ge çalışmaları ile misafir istek, ihtiyaç ve beklentilerini belirlemek hatta öngörmek, rakipleri ve teknolojiyi yakından takip ederek sektörel değişim ve gelişimleri işletme süreçlerine uyarlamak, tedarikçiler, danışmanlar, akademisyenlerden görüş almak, sektörel yayınları takip ederek gelişim ve değişimleri uyarlamak hatta farklılıklar sunmak işletmelerin yenilik sürecine katkı sağlayacaktır. Araştırma sonuçları ArGe faaliyetlerini gerçekleştiren otel işletmelerinin gerçekleştirmeyen otel işletmelerine göre ürün ve hizmete, sürece ve örgüte ilişkin boyutlara daha fazla eğilim gösterdiklerini, yenilik yönetimini uyguladıklarını ve daha yenilikçi yapıda bir örgüt kültürüne sahip olduklarını ortaya koymuştur (Tekin,2012). Bu nedenle bu çalışma kapsamında Ar-Ge departmanı bulunan on alt otel işletmesinin genel müdürleri ile görüşmek üzere talepte bulunulmuş, alt otel işletmesinden olumlu yanıt alınmıştır. Araştırmaya katkıda bulunmak isteyen alt otelin ortak özellikleri; on iki ay açık kalmasının yanında, yedi ay yüksek doluluklarla ultra her şey dâhil konsepti ile faaliyet göstermeleri ve beş ay boyunca golf ile kongre turizmine göre faaliyetlerini planlamalarıdır. $\mathrm{Bu}$ oteller yaz sezonunda açık alanlarında bulunan tüm iskele, restoranlar, havuzlar ve kaydıraklar gibi hizmet alanlarını tam kapasiteyle çalıştırırken, kış sezonunda hava şartlarından dolayı hizmeti kapalı mekânlarla sınırlandırmaktadırlar. Bu nedenle yaz sezonundaki gelir ve giderleri ile kış sezonundaki gelir ve giderleri değişiklik göstermektedir. Kriz dönemlerinde ise yüksek doluluklarla geçmesi beklenen dönemde de doluluklarda dalgalanmalar yaşandı̆̆ından, otelin gelir gider dengesi etkilenmektedir. Dolayısıyla kriz olmayan dönemlerde uygulanan planlama dışında giderlerde önlem alma ihtiyacı duyulmaktadır. Araştırmaya katılan yöneticiler, bu önlemlerin tecrübeye dayalı alınabildiği gibi uzmanların görüşlerini dikkate alan bilimsel yöntemlerle de desteklenebilmesinin güzel bir firsat olduğunu belirtmişlerdir.

Çok kriterli karar verme yöntemlerinin kullanımında genellikle uzman görüşlerinden faydalanılmaktadır. Yöntemin uygulanmasında uzman görüş sayısı ile ilgili literatürde bir genelleme bulunmamaktadır. Genel müdürlerin görüşlerinden ve ilgili literatürden ve yararlanarak, kriz dönemlerinde beş yıldızlı otel işletmelerinde uygulanabilecek tasarruf stratejileri, aşağıdaki şekilde tespit edilmiştir.

- Tüm departmanlarda personel sayısını azaltmak (K1)

- Personelleri tasarruf tedbirleri konusunda ve birden fazla işi yapabilmeleri konusunda eğitmek (K2),

- Misafirleri aynı blokta konaklatmak (K3),

- Verimliliği arttırmak için iş süreçlerini yeniden tasarlamak (K4),

- Operasyonun daha etkin kontrolü için yeni bilgi sistemleri teknolojilerinden yararlanmak (K5),

- Satıılarla fiyat ve ödeme şartları konusunda yeni düzenlemeler yapmak (K6).

- Maliyeti yüksek olan ürün ve hizmetleri daha düşük maliyetli olanlarıyla değiştirmek (K7).

Tespit edilen tasarruf stratejileri bu çalışmada kriterler olarak ele alınmaktadır. Bu kriterlerden yararlanarak Şekil 1'de verilen bulanık DEMATEL etki karşılaştırma formu tasarlanmıştır. 
Şekil 1. Bulanık DEMATEL Etki Karşılaştırma Formu

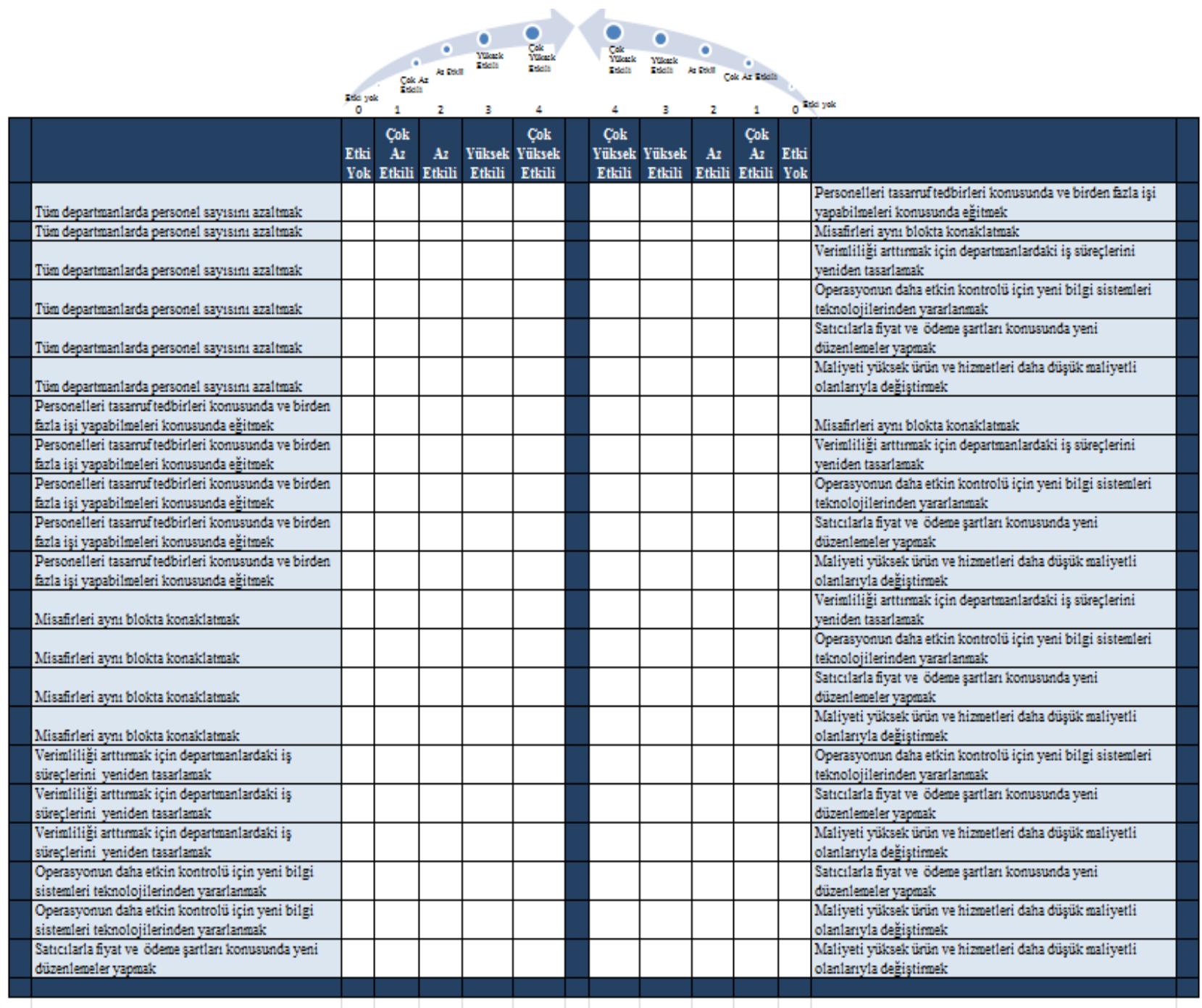

Tasarlanan formu doldurmak için Tablo 2'de verilmiş olan bulanık DEMATEL yöntemi karşılaştırma ölçeği kullanılmıştır. Formlar Antalya'da faaliyet gösteren ve Ar-Ge departmanına sahip beş yıldızlı otellerin genel müdürlerinden randevu alınarak yüz yüze görüşmeler neticesinde doldurulmuştur. Görüşme sırasında öncelikle sol kolonda bulunan kriterin sağ kolonda bulunan kritere etkisi değerlendirilip sol hanede ilgili değerin karşısına işaret koymaları istenmiştir. Daha sonra aynı iki kriterin bu sefer sağ kolonunda bulunan kriterin sol kolonda bulunan kritere ektisi değerlendirilip sağ hanede ilgili değerin karşısına işaret koymaları istenmiş ve bu işlemlerin her satır için yapılması sağlanmıştı. Formların yüz yüze doldurulmasının sebebi seçilen ölçeğin yöneticiler tarafindan doğru algılandığından emin olunmasının istenmesidir. Otel genel müdürleri ile görüşmeler sırasında puanlamalar yapılırken her puanlama için örnekler üzerinde tartı̧̧larak etkilerin derecesi detaylı bir şekilde irdelenmiştir.

\section{Adım: Bulanık Direkt İlişki Matrisinin Oluşturulması}

Bu adımda genel müdürlerin ikili karşılaştırmalar yaparak doldurdukları formlar Tablo 3'de verildiği şekilde matris haline getirilmiştir. Tablo 3 sadece bir yönetici tarafindan yapılan bir değerlendirme olup örnek olması için verilmiştir. Diğer otel yöneticileri ile yapılan değerlendirmeler aynı şekilde bulanık matris haline getirilerek ortalamalar alınmıştır. Ortalama direkt ilişki matrisi Tablo 4'de görülmektedir. 
N. Eksili - Z. Unal - E. I. Cetin

Tablo 3. Formlardan Elde Edilen Bilgilerin Bulanık Matris Şeklinde Gösterimi

\begin{tabular}{|c|c|c|c|c|c|c|c|}
\hline Kriter & K1 & K2 & K3 & K4 & K5 & K6 & K7 \\
\hline K1 & $(0 ; 0 ; 0,25)$ & $(0,25 ; 0,5 ; 0,75)$ & $(0 ; 0,25 ; 0,5)$ & $(0 ; 0,25 ; 0,5)$ & $(0 ; 0 ; 0,25)$ & $(0 ; 0 ; 0,25)$ & $(0 ; 0 ; 0,25)$ \\
\hline K2 & $(0,5 ; 0,75 ; 1)$ & $(0 ; 0 ; 0,25)$ & $(0,25 ; 0,5 ; 0,75)$ & $(0,75 ; 1 ; 1)$ & $(0 ; 0 ; 0,25)$ & $(0 ; 0 ; 0,25)$ & $(0 ; 0 ; 0,25)$ \\
\hline K3 & $(0,25 ; 0,5 ; 0,75)$ & $(0 ; 0,25 ; 0,5)$ & $(0 ; 0 ; 0,25)$ & $(0,5 ; 0,75 ; 1)$ & $(0 ; 0 ; 0,25)$ & $(0 ; 0 ; 0,25)$ & $(0 ; 0 ; 0,25)$ \\
\hline K4 & $(0,25 ; 0,5 ; 0,75)$ & $(0,5 ; 0,75 ; 1)$ & $(0 ; 0,25 ; 0,5)$ & $(0 ; 0 ; 0,25)$ & $(0,25 ; 0,5 ; 0,75)$ & $(0 ; 0 ; 0,25)$ & $(0 ; 0,25 ; 0,5)$ \\
\hline K5 & $(0 ; 0 ; 0,25)$ & $(0 ; 0 ; 0,25)$ & $(0 ; 0 ; 0,25)$ & $(0 ; 0,25 ; 0,5)$ & $(0 ; 0 ; 0,25)$ & $(0 ; 0 ; 0,25)$ & $(0,25 ; 0,5 ; 0,75)$ \\
\hline K6 & $(0 ; 0 ; 0,25)$ & $(0 ; 0 ; 0,25)$ & $(0 ; 0 ; 0,25)$ & $(0 ; 0 ; 0,25)$ & $(0 ; 0 ; 0,25)$ & $(0 ; 0 ; 0,25)$ & $(0,5 ; 0,75 ; 1)$ \\
\hline K7 & $(0 ; 0 ; 0,25)$ & $(0 ; 0 ; 0,25)$ & $(0 ; 0 ; 0,25)$ & $(0,5 ; 0,75 ; 1)$ & $(0 ; 0 ; 0,25)$ & $(0 ; 0 ; 0,25)$ & $(0 ; 0 ; 0,25)$ \\
\hline
\end{tabular}

Tablo 4. Ortalama Bulanık Direkt Ilişki Matrisi

\begin{tabular}{|c|c|c|c|c|c|c|c|}
\hline K & K1 & K2 & K3 & K4 & K5 & K6 & K7 \\
\hline K1 & $(0 ; 0 ; 0,25)$ & $(0,17 ; 0,33 ; 0,54)$ & $(0,17 ; 0,38 ; 0,58)$ & $(0,21 ; 0,38 ; 0,58)$ & $(0,13 ; 0,21 ; 0,42)$ & $(0 ; 0 ; 0,25)$ & $(0,04 ; 0,08 ; 0,33)$ \\
\hline K2 & $(0,54 ; 0,75 ; 0,88)$ & $(0 ; 0 ; 0,25)$ & $(0,21 ; 0,38 ; 0,58)$ & $(0,25 ; 0,42 ; 0,63)$ & $(0,04 ; 0,08 ; 0,33)$ & $(0 ; 0,04 ; 0,29)$ & $(0 ; 0,04 ; 0,29)$ \\
\hline K3 & $(0,5 ; 0,75 ; 0,92)$ & $(0,17 ; 0,33 ; 0,58)$ & $(0 ; 0 ; 0,25)$ & $(0,38 ; 0,63 ; 0,83)$ & $(0,08 ; 0,17 ; 0,42)$ & $(0,04 ; 0,08 ; 0,33)$ & $(0,04 ; 0,13 ; 0,38)$ \\
\hline K4 & $(0,33 ; 0,54 ; 0,75)$ & $(0,42 ; 0,67 ; 0,92)$ & $(0,25 ; 0,42 ; 0,63)$ & $(0 ; 0 ; 0,25)$ & $(0,29 ; 0,46 ; 0,67)$ & $(0,04 ; 0,13 ; 0,38)$ & $(0,17 ; 0,33 ; 0,58)$ \\
\hline K5 & $(0,25 ; 0,46 ; 0,67)$ & $(0,21 ; 0,38 ; 0,58)$ & $(0 ; 0,08 ; 0,33)$ & $(0,29 ; 0,5 ; 0,71)$ & $(0 ; 0 ; 0,25)$ & $(0 ; 0,08 ; 0,33)$ & $(0,17 ; 0,29 ; 0,54)$ \\
\hline K6 & $(0,08 ; 0,13 ; 0,38)$ & $(0,04 ; 0,08 ; 0,33)$ & $(0,08 ; 0,13 ; 0,38)$ & $(0,04 ; 0,08 ; 0,33)$ & $(0,04 ; 0,08 ; 0,33)$ & $(0 ; 0 ; 0,25)$ & $(0,46 ; 0,71 ; 0,92)$ \\
\hline K7 & $(0 ; 0 ; 0,25)$ & $(0 ; 0 ; 0,25)$ & $(0 ; 0,04 ; 0,29)$ & $(0,17 ; 0,25 ; 0,5)$ & $(0 ; 0,04 ; 0,29)$ & $(0,08 ; 0,17 ; 0,42)$ & $(0 ; 0 ; 0,25)$ \\
\hline
\end{tabular}

\section{Adım: Normalleştirilmiş Bulanık Direkt Iliş̧ki Matrisinin Oluşturulması}

Elde edilen ortalama bulanık direkt ilişki matrisi (7) ve (8) nolu formüller kullanılarak normalleştirilmiş ve normalleştirilmiş bulanık direkt ilişki matrisi Tablo 5'teki gibi oluşmuştur.

Tablo 5. Normalleştirilmiş Bulanık Direkt ilişki Matrisi

\begin{tabular}{|c|c|c|c|c|c|c|c|}
\hline K & K1 & K2 & K3 & K4 & K5 & K6 & K7 \\
\hline K1 & $(0 ; 0 ; 0)$ & $(0,1 ; 0,13 ; 0,13)$ & $(0,1 ; 0,14 ; 0,14)$ & $(0,12 ; 0,14 ; 0,14)$ & $(0,07 ; 0,08 ; 0,1)$ & $(0 ; 0 ; 0,06)$ & $(0,02 ; 0,03 ; 0,08)$ \\
\hline K2 & $(0,32 ; 0,29 ; 0,21)$ & $(0 ; 0 ; 0)$ & $(0,12 ; 0,14 ; 0,14)$ & $(0,15 ; 0,16 ; 0,15)$ & $(0,02 ; 0,03 ; 0,08)$ & $(0 ; 0,02 ; 0,07)$ & $(0 ; 0,02 ; 0,07)$ \\
\hline K3 & $(0,29 ; 0,29 ; 0,22)$ & $(0,1 ; 0,13 ; 0,14)$ & $(0 ; 0 ; 0)$ & $(0,22 ; 0,24 ; 0,2)$ & $(0,05 ; 0,06 ; 0,1)$ & $(0,02 ; 0,03 ; 0,08)$ & $(0,02 ; 0,05 ; 0,09)$ \\
\hline K4 & $(0,2 ; 0,21 ; 0,18)$ & $(0,24 ; 0,25 ; 0,22)$ & $(0,15 ; 0,16 ; 0,15)$ & $(0 ; 0 ; 0)$ & $(0,17 ; 0,17 ; 0,16)$ & $(0,02 ; 0,05 ; 0,09)$ & $(0,1 ; 0,13 ; 0,14)$ \\
\hline K5 & $(0,15 ; 0,17 ; 0,16)$ & $(0,12 ; 0,14 ; 0,14)$ & $(0 ; 0,03 ; 0,08)$ & $(0,17 ; 0,19 ; 0,17)$ & $(0 ; 0 ; 0)$ & $(0 ; 0,03 ; 0,08)$ & $(0,1 ; 0,11 ; 0,13)$ \\
\hline K6 & $(0,05 ; 0,05 ; 0,09)$ & $(0,02 ; 0,03 ; 0,08)$ & $(0,05 ; 0,05 ; 0,09)$ & $(0,02 ; 0,03 ; 0,08)$ & $(0,02 ; 0,03 ; 0,08)$ & $(0 ; 0 ; 0)$ & $(0,27 ; 0,27 ; 0,22)$ \\
\hline K7 & $(0 ; 0 ; 0,06)$ & $(0 ; 0 ; 0,06)$ & $(0 ; 0,02 ; 0,07)$ & $(0,1 ; 0,1 ; 0,12)$ & $(0 ; 0,02 ; 0,07)$ & $(0,05 ; 0,06 ; 0,1)$ & $(0 ; 0 ; 0)$ \\
\hline
\end{tabular}

\section{Adım: Bulanık Toplam İlişki Matrisinin Oluşturulması}

Bir önceki adımda elde edilen normalleştirilmiş bulanık direkt ilişki matrisi $A_{l}, A_{m}$ ve $A_{u}$ olmak üzere üç ayrı matrise ayrılmış ve bu matrisler tek tabloda aşağıda verilmiştir. 
Tablo 6. $A_{1}, A_{m}, A_{u}$ matrisi

\begin{tabular}{|c|c|c|c|c|c|c|c|c|c|c|c|c|c|c|c|c|c|c|c|c|c|}
\hline \multirow{2}{*}{$\mathrm{K}$} & \multicolumn{7}{|c|}{$A_{l}$} & \multicolumn{7}{|c|}{$A_{m}$} & \multicolumn{7}{|c|}{$\mathbf{A}_{\mathrm{u}}$} \\
\hline & K1 & K2 & К3 & K4 & K5 & К6 & K7 & K1 & K2 & K3 & K4 & K5 & K6 & K7 & K1 & K2 & Кз & K4 & K5 & K6 & K7 \\
\hline K1 & 0 & 0,1 & 0,1 & 0,12 & 0,07 & 0 & 0,02 & 0 & 0,13 & 0,14 & 0,14 & 0,08 & 0 & 0,03 & 0 & 0,13 & 0,14 & 0,14 & 0,1 & 0,06 & 0,08 \\
\hline K2 & $\mid 0,32$ & 0 & 0,12 & 0,15 & 0,02 & 0 & 0 & 0,29 & 0 & 0,14 & 0,16 & 0,03 & $\mid 0,02$ & 0,02 & 0,21 & 0 & 0,14 & 0,15 & 0,08 & $\mid 0,07$ & 0,07 \\
\hline K3 & 0,29 & 0,1 & 0 & 0,22 & 0,05 & 0,02 & 0,02 & 0,29 & 0,13 & 0 & 0,24 & 0,06 & 0,03 & 0,05 & 0,22 & 0,14 & 0 & 0,2 & 0,1 & 0,08 & 0,09 \\
\hline K4 & 0,2 & 0,24 & 0,15 & 0 & 0,17 & 0,02 & 0,1 & 0,21 & 0,25 & 0,16 & 0 & 0,17 & 0,05 & 0,13 & 0,18 & 0,22 & 0,15 & 0 & 0,16 & 0,09 & 0,14 \\
\hline K5 & 0,15 & 0,12 & 0 & 0,17 & 0 & 0 & 0,1 & 0,17 & 0,14 & 0,03 & 0,19 & 0 & 0,03 & 0,11 & 0,16 & 0,14 & 0,08 & 0,17 & 0 & 0,08 & 0,13 \\
\hline K6 & 0,05 & 0,02 & 0,05 & 0,02 & 0,02 & 0 & 0,27 & 0,05 & 0,03 & 0,05 & 0,03 & 0,03 & 0 & 0,27 & 0,09 & 0,08 & 0,09 & 0,08 & 0,08 & 0 & 0,22 \\
\hline K7 & 0 & 0 & 0 & 0,1 & 0 & 0,05 & 0 & 0 & 0 & 0,02 & 0,1 & 0,02 & 0,06 & 0 & 0,06 & 0,06 & 0,07 & 0,12 & 0,07 & 0,1 & 0 \\
\hline
\end{tabular}

\section{Adım: Etkilenen ve Etkileyen Grupların Belirlenmesi}

Bu adımda DEMATEL yönteminin anlatıldığı kısımda yer alan (5) ve (6) nolu formüller $A_{l}, A_{m}$ ve $A_{u}$ matris için ayrı ayrı uygulanmıştır. Etki diyagramında yatay eksen dikey eksen değerleri $r_{1}+c_{1}, r_{1}-c_{l}, r_{m}+$

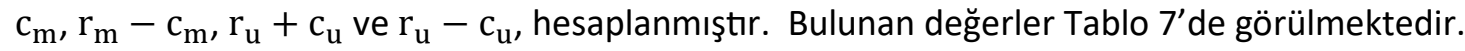

\section{Adım: Durulaştırma}

Bulanık sayıları durulaştırmak için (9) ve (10) nolu formüller kullanılarak sonuçlar Tablo 7'de gösterilmiştir. Durulaştırımış bu değerler etki diyagramını çizmek için kullanılmıştır. Oluşturulan etki diyagramı Şekil 2'de verilmiştir.

\section{Adım: Kriterlerin Ağırlıklarının Belirlenmesi}

Kriter ağırlıkları ise (11) ve (12) nolu formüller kullanılarak hesaplanmıştır. Elde edilen ağırlıklar Tablo 7'de görülmektedir.

Tablo 7. r ve c Değerleri

\begin{tabular}{|c|c|c|c|c|c|c|}
\hline & $\mathbf{r + c}$ & $\mathbf{r - c}$ & $\mathbf{( r + c ) ^ { \text { def } }}$ & $\mathbf{~}^{\mathbf{r}-\mathbf{c})^{\text {def }}}$ & $\mathbf{w}_{\mathbf{i}}$ & $\mathbf{W}$ \\
\hline K1 & $(3,32 ; 4,45 ; 6,15)$ & $(-1,2 ;-1,15 ;-0,91)$ & 4,59 & $-1,10$ & 4,72 & 0,178 \\
\hline K2 & $(2,92 ; 4,01 ; 5,89)$ & $(0,01 ;-0,09 ;-0,19)$ & 4,21 & $-0,09$ & 4,21 & 0,159 \\
\hline K3 & $(2,76 ; 4,02 ; 5,93)$ & $(0,6 ; 0,63 ; 0,55)$ & 4,18 & 0,60 & 4,22 & 0,159 \\
\hline K4 & $(3,71 ; 5 ; 6,85)$ & $(0,2 ; 0,26 ; 0,26)$ & 5,14 & 0,25 & 5,15 & 0,194 \\
\hline K5 & $(2,14 ; 3,17 ; 5,32)$ & $(0,34 ; 0,68 ; 0,57)$ & 3,45 & 0,57 & 3,49 & 0,132 \\
\hline K6 & $(1 ; 1,53 ; 4,31)$ & $(0,58 ; 0,49 ; 0,48)$ & 2,09 & 0,51 & 2,15 & 0,081 \\
\hline K7 & $(1,28 ; 1,96 ; 4,66)$ & $(-0,53 ;-0,81 ;-0,77)$ & 2,46 & $-0,73$ & 2,57 & 0,097 \\
\hline
\end{tabular}

Şekil 2. Etki Diyagramı

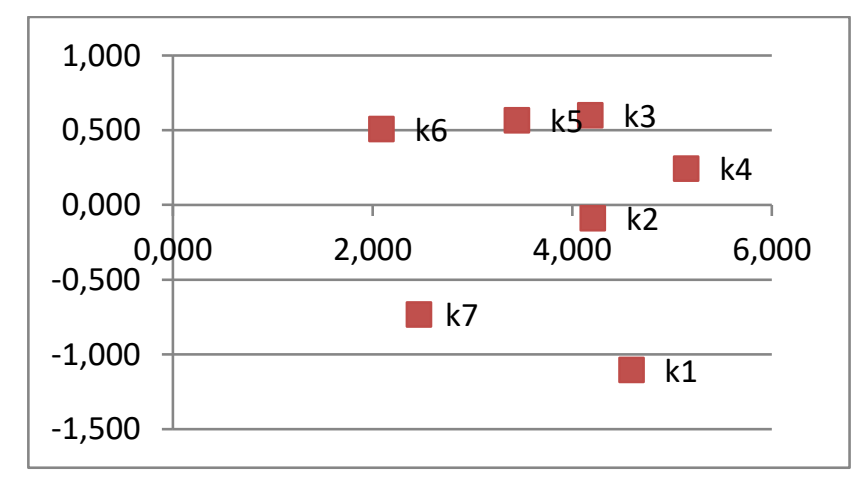


Şekil 2' de görüldüğü gibi kriz karşısında alınabilecek tasarruf stratejileri r-c değerinin (-) veya (+) değer almasına göre iki gruba ayrılmaktadır. Kriz karşısında tasarruf stratejisi uygulayacak beş yıldızlı otel işletmeleri için "Misafirleri aynı blokta konaklatmak" (k3), "Verimliliği arttırmak için iş süreçlerini yeniden tasarlamak" (k4), "Operasyonun daha etkin kontrolü için yeni bilgi sistemleri teknolojilerinden yararlanmak" (k5), ve "Satıcılarla fiyat ve ödeme şartları konusunda yeni düzenlemeler yapmak" (k6) etkili kriterler olarak karşımıza çıkmaktadır. Yine benzer şekilde "Maliyeti yüksek ürün ve hizmetleri daha düşük maliyetli olanlarıyla değiştirmek" (k7), "Personelleri tasarruf tedbirleri konusunda ve birden fazla işi yapabilmeleri konusunda eğitmek" (k2) ve "Tüm departmanlarda personel sayısını azaltmak" (k1) stratejileri de diğer stratejilerden etkilenen kriterler olarak göze çarpmaktadır.

Kriterler arasındaki ilişkiyi gösteren $r+c$ değerlerine göre "Verimliliği arttırmak için iş süreçlerini yeniden tasarlamak" ( $k 4)$ ve "Tüm departmanlarda personel sayısını azaltmak" (k1) kriterlerinin diğer kriterlerle daha fazla ilişki içinde olduğunu söylemek mümkündür. Tasarruf stratejileri içerisinde en çok önem arz eden kriter iş süreçlerinin yeniden tasarlanması (k4) olarak karşımıza çıkmaktadır. Etki diyagramına göre "Tüm departmanlarda personel sayısını azaltmak" (k1) tasarruf stratejisi alınan diğer tasarruf stratejilerinden en çok etkilenen kriter olarak göze çarpmaktadır. Konaklama sektöründe kriz döneminde etkili bir strateji olarak düşünülen personel sayısını azaltmanın diğer stratejilerin bir sonucu olarak meydana gelmekte olduğu görülmektedir.

"Personelleri tasarruf tedbirleri konusunda ve birden fazla işi yapabilmeleri konusunda eğitmek" (k2) kriterinin ise en büyük ikinci $r+c$ değerine sahip olmasına rağmen $r-c$ değerinin 0 'dan çok az farklı $(-0,09)$ olduğu, dolayısıyla diğer tasarruf stratejilerinden en az etkilenen kriter olduğu söylenebilir.

\section{Sonuç ve Öneriler}

Üst kademe yöneticilerinin verdikleri kararların çoğu stratejik niteliktedir. Çoğu zaman programlanamayan ve belirsizlik şartları altında verilen bu kararlar kriz dönemlerini de kapsamaktadır. Ancak kriz dönemlerinde alınan kararlar işletmelerin gelecek planlarından ziyade, hayatta kalma stratejilerini içermektedir. Özellikle turizm sektörü gibi ekonomik, siyasi ve uluslararası birçok farklı değişkenden kolaylıkla etkilenen sektörlerde bu kararları vermek oldukça risklidir.

Bu çalışmada kriz dönemlerinde beş yıldızlı otel işletmelerinin dikkate aldığı tasarruf stratejileri arasındaki ilişkiler Bulanık DEMATEL yöntemi ile analiz edilmiştir. DEMATEL yöntemi, değişkenleri bir sebep ve sonuç ilişkisine dayandırarak, yöneticilerin değişkenler arasındaki ilişkileri tam olarak algılamasını sağlamaktadır.

Çalışmada beş yıldızı otel işletmeleri için misafirlerin aynı blokta konaklatılması, verimliliğin arttrılması için iş süreçlerinin yeniden tasarlanması, operasyonun daha etkin kontrolü için yeni bilgi sistemleri teknolojilerinden yararlanılması ve satıcılarla, fiyat düşürülmesi veya ödeme sürelerinin uzatılması gibi fiyat ve ödeme şartları konusunda yeni düzenlemeler yapılması kriterlerinin etkili kriterler olarak öne çıktı̆ı görülmektedir.

Misafirlerin farklı bloklara dağıtılarak konaklatılması gerek enerji giderleri gerek personel giderleri açısından maliyete sebep olmaktadır. Doğacak olan ışıklandırma, ısıtma ve soğutma giderlerinin enerji maliyetlerini arttıracağı aşikârdır. Bunun yanında farklı bloklarda görevlendirilecek çalışanların faaliyetleri hareket ve zaman etkinliği açısından verimli olmayacaktır. Bu nedenle misafirlerin aynı blokta konaklatılması tasarruf stratejileri içinde etkili bir kriter olarak görülmüştür. Konaklama işletmelerinde iş süreçleri genel olarak işletmenin tam kapasiteyle çalıştı̆ı dönemlerde mevsimsel değişiklikler göz önüne alınarak tasarlanmaktadır. Ancak kriz dönemlerinde müşteri sayılarındaki dalgalanmalar iş süreçlerinin yeniden tasarlanmasını gerektirmektedir. Örneğin otelin, kriz olmadığı dönemlerdeki satın alma süreçleri stoklama prensibiyle çalışırken kriz dönemlerinde talebe göre satın alma ve minimum stok seviyesine göre depolama stratejisi uygulanabilmektedir. Bu nedenle iş süreçlerinin tasarımı da etkili bir kriter olarak öne çıkmıştır. Konaklama işletmelerinde yeni bir bilgi teknolojisinin satın alınması ise başlangıçta büyük bir maliyet kalemi olarak görünse de zaman içerisinde yapılan hataları minimize etmeye yönelik çalışarak operasyonların işleyişini daha etkin hale getirmektedir. Konaklama işletmesi giderlerinin yaklaşık \%25'ini oluşturan satın alma 
giderleri kriz dönemlerinde müdahale edilmesi de üzerinde durulması gereken en önemli tasarruf kalemlerindendir. Bu dönemlerde satıcılarla mevcut anlaşmaların dışına çıkılarak gerek ödeme sürelerinin uzatılması gerekse satın alınacak ürün veya hizmet fiyatlarının düşürülmesi gündeme gelmektedir. Kriz dönemlerinde sadece oteller değil piyasadan ötürü satıcı firmalar da kriz içinde olduğundan maliyetlerinin altında satı̧ yapmak zorunda kalmaktadır. Bu durumda konaklama işletmeleri satıcılarla uygun şartları yakalamak için uygun şartlarda anlaşmalar yapabilmektedir.

Maliyeti yüksek ürün ve hizmetlerin daha düşük maliyetli olanlarıyla değiştirilmesi, personellerin tasarruf tedbirleri ve birden fazla işin yapılması konusunda eğitilmesi, tüm departmanlarda personel sayısını azaltılması stratejileri ise diğer stratejilerden etkilenen kriterler olarak göze çarpmaktadır.

Örneğin kriz dönemlerinde kat hizmetlerinden yiyecek-içecek departmanına hatta eğlence aktivite departmanlarına kadar kullanılan tüm ürün ve hizmetlerin daha düşük maliyetli olanlarla değiştirilmesi gerekebilir. Ancak yapılacak bu değişilikliklerin müşterinin az talep ettiği ürün ve hizmetlerin belirlenerek gerçekleştirilmesi müşteri memnuniyetinin düşmemesini sağlayacaktır. Personelin tasarruf tedbirleri ve birden fazla işin yapılması konusunda eğitilmesi dikkat edilmesi gereken diğer önemli bir husustur. Konaklama işletmelerinde çalışan personelin pozisyonların görev tanımları kriz olmayan dönemler için tasarlanmıştır Ancak kriz dönemlerinde yaşanacak müşteri sayılarındaki dalgalanmaları göz önünde bulundurarak belirlenmiş olan görev tanımlarında işlerin daha etkin şekilde yürütülmesi amacıyla bir takım düzenlemeler yapılabilir. Personel giderleri konaklama işletmesi giderlerinin yaklaşık \% 45'ini oluşturmaktadır. Bu nedenle kriz dönemlerinde ilk akla gelen tasarruf kalemlerindendir. Oysa sanılanın aksine kriz anında kısa sürede personel çıkarmak uzun vadede işletmeyi olumsuz etkilemektedir. Personel çıkarmada uygulanan kriterlerin belirsizliği ve hızlı kararlar vererek personelin işten çıkarılması neticesinde katlanılması gereken işten çıkarma maliyetleri bulunmaktadır. Issten çıkarma maliyetleri uzun vadede olumsuz etkilerin bir kısmını oluşturmaktadır. Buna ek olarak krizin süresi bilinmediğinden tekrar işe alma sürecinde katlanılması gereken seçme ve yerleştirme maliyetlerinin de hesaba katılması gerekmektedir.

DEMATEL yöntemi gibi analitik bir yöntemin stratejik karar vermede kullanılması hem yöneticileri sübjektiflikten uzaklaştıracak hem de daha elle tutulur karar verilmesini sağlayacaktır. Konaklama ve turizm alanında çok kriterli karar verme yöntemlerinin kullanıldığı çalışmaların sınırlı olduğu görülmektedir. Turizm sektöründe karar vermeyi gerektirecek pek çok operasyonel ve stratejik karar olduğu düşünüldüğünde bu ve benzer yöntemlerin birer karar destek aracı olarak kullanılabileceği görülmektedir. Çalışmada ele alınan tasarruf stratejileri yerine başka stratejiler düşünülebileceği gibi AHP, TOPSIS, VIKOR gibi farklı çok kriterli karar verme yöntemleri kullanılarak karşılaştırmalar yapılması da mümkündür.

\section{Kaynaklar}

Akdemir, A.(2009). Işletmeciliğin temel bilgileri. Ankara: Ekin Basım Yayın Dağıtım.

Aksakal, E., \& Dağdeviren, M. (2010). ANP ve DEMATEL yöntemleri ile personel seçimi problemine bütünleşik bir yaklaşım. Gazi Üniversitesi Mühendislik-Mimarlık Fakültesi Dergisi, 25(4), 905-913.

Bahar, E., Kaya, F., \& Keklik, F. (2011). Konaklama sektöründe krizle mücadele stratejileri. Uluslararsı iktisadi ve idari incelemeler Dergisi, (6), 83-100.

Bali, Ö., Tutun, S., Pala, A., \& Çörekçi, C. (2014). A MCDM Approach with fuzzy DEMATEL and Fuzzy TOPSIS for 3PL provider selection. Sigma 32, Journal of Engineering and Natural Sciences, 222-239.

Boyd, H. W., \& Walker, O. C. (1999). Marketing management. Boston: Richard D. Irwin.

Chen, C. A. (2012). Using DEMATEL method for medical tourism development in Taiwan. . American Journal of Tourism Research, 1(1), 26-32.

Chowdhury, S. (2002). Turnarounds: A stage theory perspective. Canadian Journal of Administrative Sciences, 19(3), 249-266.

Coombs, T. (1999). Ongoing crisis communication: Planning, managing and responding. Thousand Oakes, CA: Sage.

Çelik, C., \& Özdevecioğlu, M. (2002). Otel işletmelerinin ekonomik krizden etkilenme düzeyleri ve kriz dönemlerinde uyguladıkları politikalara ilişkin bir araştırma. Çukurova Üniversitesi Sosyal Bilimler Enstitüsü Dergisi, 9 (9), 56-74. 
Davies, H., \& Walters, M. (1998). Do all crises have to become disasters? Risk and risk mitigation. Disaster Prevention and Management, 7 (5), 396-400.

Eren, E. (2013). Stratejik yönetim ve işletme politikası. İstanbul: Beta.

Eroğlu, Ö., Canlı, A. K., \& Gülşan, O. (2015). Tehlikeli madde taşımacılığı firma seçimi için gerekli niteliklerin belirlenmesi. IV. Ulusal Lojistik Ve Tedarik Zinciri Kongresi , 298-308.

Faulkner, B. (2001). Towards a framework for tourism disaster management. Tourism Management, 22 (2), $135-147$.

Hwang, B., Pai, N., Lu, C., \& Ken, y. (2014). The design decision of online game development based on a MCDM model combining DEMATEL with ANP Method. Journal of Theoretical and Applied Information Technology, 63(2) , 486498.

Jessop, B. (1999). Globalisatoon and the Asia-Pacific: Contested territories. K. Olds, P. Dicken, P. F. Kelly, \& L. Kong (Dü) içinde, Reflections on globalisation and its (il)logic(s). London: Routledge.

Kash, T., \& Darling, J. (1988). Crises management: Prevention, diagnosis and intervention. Leadership and Organization Development Journal , 19 (4), 179-186.

Mitroff, I. L. (2000). How to keep a crises from happening. Harvard Management Update, 5-12.

Okumus, F., Altinay, M., \& Arasli, H. (2005). The impact of Turkey's economic crisis of February 2001 on the tourism industry in Northern Cyprus. Tourism Management (26), 95-104.

Organ, A. (2013). Bulanık dematel yöntemiyle makine seçimini etkileyen kriterlerin değerlendirilmesi. Çukurova Üniversitesi Sosyal Bilimler Enstitüsü Dergisi, 22(1), 157-172.

Parsons, W. (1996). Crisis management. Career Development International, 1 (5), 26-28.

Pearce, J., \& Robbins, D. (2008). Strategic transformation as the essential last step in the process of business turnaround. Business Horizons, 21 (2), 121-130.

Ritchie, B. W. (2004). Chaos, crises and disasters: a strategic approach to crisis management in the tourism industry. Tourism Management, 25(6), 669-683.

Saeidipour, B., \& Ismaeli, S. (2012). A study of how to implement a successful CRM by identifying challenges using DEMATEL method: An empirical study on small to medium business units. Management Science Letters, 2(1), 363-368.

Solnet, D. J., Paulsen, N., \& Cooper, C. (2010). Decline and turnaround: a literature review and proposed research agenda for the hotel sector. Current Issues in Tourism, 13 (2), 139-159.

Türker, T. (2012). Üniversitelerde bölümlerin performanslarinin değerlendirilmesinde bulanik dematel ve veri zarflama analizi (vza) yöntemlerinin kullanimi. Karabük: Karabük Üniversitesi, Fen Bilimleri Enstitüsü.

Ülgen, H., \& Mirze, S. (2013). İşletmelerde stratejik yönetim. İstanbul: Beta.

Whitlaa, P., Waltersb, P. G., \& Davies, H. (2007). Global strategies in the international hotel industry. Hospitality Management, 26, 777-792.

Wu, W., \& Lee, Y. (2007). Developing global managers' competencies using the fuzzy DEMATEL method. Expert Systems with Applications, 32, 499-507.

Wu, K. Y., Zheng, M. J., Lu, S. C., \& Wu, Y. (2013). Applying DEMATEL method to the study on sustainable management of low-carbon tourism for Cultural heritage conservation. Recent Advances in Energy, Environment, Economics and Technological Innovation, 96-102. 
This Page Intentionally Left Blank 